DOI 10.31558/2519-2949.2021.3.18

УДК 339.9(477):622.691(4)

ORCID ID: https://orcid.org/0000-0002-1378-3396

Котик Ю. В., Донецький національний університет імені Василя Стуса

\title{
ДОБУДОВА «ПІВНІЧНОГО ПОТОКУ-2» У КОНТЕКСТІ ЗОВНІШНЬОЕКОНОМІЧНОЇ БЕЗПЕКИ УКРАЇНИ
}

У статті розкриваються сутнісні характеристики впливу побудови «Північного потоку-2» на зовнішньоекономічну безпеку Украӥни, що підтвержує зростаючу актуальність економічної безпеки у порядку денному теорії і практики начіональної безпеки в цілому. Доводиться, що «розиирене» тлумачення енергетичної безпеки дозволяє вийти за рамки економіко-технологічного бачення проблеми і розглядати ї̈ як суспільно-політичну складову, яка набула нового виміру у якості впливового інструменту у світовій політичі. Питання поставок енергоносї̈в з Росії в Свропу наочно демонструє взаємозалежність енергетичної безпеки Свропи і України. Гібридна війна Росії проти Украӥни доводить взаємовпливовість всіх секторів безпеки: військового, політичного, економічного, сочіального та екологічного з інтегруючим політичним, що відповідає підходу Копенгагенської школи до розуміння міжнародної безпеки. Стверджується залежнісить зовнішньоекономічної та загалом національної безпеки Украйни. від збереження потужностей транзиту украӥнською ГТС та добудови «Північого потоку-2 3'ясовані об'єктивні та суб'єктивні чинники які вплинули на прокладання газогону «Північний потік-2», роль США, СС, Росії та України у изьому процесі. Оскільки проаналізована угода між США та Німеччиною від 22 липня 2021 року не гарантує зовнішньоекономічної безпеки України, розглянуті можливі загрози після добудови «Північного потоку-2»: економічні, екологічні та політико-безпекові. 3 огляду на складний технологічний, юридичний і політичний механізм прийняття в експлуатацію російського газопроводу, окреслено можливі подальші кроки України, необхідні для нейтралізаиії негативних наслідків иього проєкту. Акиентується увага на необхідності створення об'єднаного фронту протидї̈ російській гібридній війні шляхом повернення ключових європейських спожсвачів російського газу до иіннісних засад у своєму ставлення до політики Кремля.

Ключові слова: зовнішньоекономічна безпека, енергетична безпека, економічна дипломатія, «Північний потік-2», національні інтереси.

Постановка проблеми

Економічна безпека держави у XXI столітті є багатовимірною і багаторівневою. Зокрема, іiі енергетична складова набула актуальності не лише у контексті забезпечення ресурсами економіки для ефективного розвитку, але й як вагомого важелю впливу на світову політику та міжнародну безпеку. Газогін «Північний потік-2» є для Кремля важливим інструментом гібридної війни, а тому його побудова набула для України виразного безпекового виміру. Невипадково Стратегія національної безпеки України «Безпека людини - безпека країни» [24] передбачає розробку не тільки Стратегії економічної безпеки України [30], але й окремо Стратегії енергетичної безпеки України [16].

Аналіз останніх досліджень

Вплив добудови «Північного потоку-2» на зовнішньоекономічну безпеку України жваво обговорюється на національному і міжнародному рівнях, політиками та експертами, які презентують що урядовий, то й громадський сектори. Питання поставок енергоносіїв з Росії в Європу наочно демонструє взаємозалежність енергетичної безпеки Європи і України. Загалом, проблематика вивчення теми нашої статті утворює три взаємопов'язаних дослідницьких кола: економічна безпека, енергетична безпека та одночасно і безпековий вимір побудови газогону «Північний потік-2».

Не зважаючи на традиційне домінування військово-політичних аспектів безпеки в дослідженнях представників політичного реалізму, навіть вони, в особі одного із фундаторів напряму Ганса Моргентау (Hans J. Morgentau), вимушені були враховувати економічний фактор в здійсненні зовнішньої політики [36]. Глобалізація та завершення холодної війни, послаблення домінування реалістів у вивченні міжнародних відносин створили умови для закріплення економічної безпеки 
в актуальному порядку денному теорії та практики національної безпеки [33]. Щодо енергетичної складової економічної безпеки, то іiі осмислення пройшло шлях від «вузького» сприйняття як «доступності необхідних ресурсів за прийнятними цінами» до «розширеного» тлумачення за допомогою так званих, «the four As» (availability, affordability, accessibility and acceptability: наявність необхідного обсягу енергетичного ресурсу, доступність їх за ціною (фінансовоекономічний аспект), доступність ресурсу споживачеві (соціальний та інфраструктурний аспекти), прийнятність використання в контексті потенційної шкоди довкіллю (екологічний аспект) [34]. Однак новітній тренд полягає в «поглибленому» тлумаченні енергетичної безпеки в рамках підходу, що базується на врахуванні вразливостей життєво важливих енергетичних систем (a vulnerability-based approach to energy security). Алех Черп (Aleh Cherp) та Джессіка Джюелл (Jessica Jewell) вважають, що інтерпретація на основі «the four As» не надає коректних відповідей на питання: безпека для кого? безпека для яких цінностей? безпека від яких загроз? [32]. Запропонований А. Черп та Дж. Джюелл підхід дозволяє вийти за рамки переважно економіко-технологічного бачення питання, а також принципу «business as usual», розглядати енергетичну безпеку в ширшому контексті, при чому не тільки безпековому, але й суспільному. Такий підхід сприяє обгрунтуванню тези про використання енергоресурсів в якості інструмента світової політики на принципово інших ніж принципи реалполітики методологічних засадах, що $є$ вкрай важливим в ситуації з політичними та безпековими наслідками запуску «Північного потоку-2».

Безпосередньо проблема добудови «Північного потоку-2», у контексті зовнішньоекономічної безпеки України, вже отримала змістовні коментарі, як на політико-дипломатичному рівні (очільників МЗС України Д. Кулеби [27] та НАК Нафтогазу України Ю. Вітренко [3], американських дипломатів Дж. Кента [20], Дж. Гербста [35], Д. Шолле [6], Д. Фріда [35], міністра закордонних справ Польщі Зб. Рау [6], так і експертному. Серед вітчизняних авторів, відзначимо, передусім, грунтовні роботи працівників Центру глобалістики «Стратегія XXI», насамперед його президента, відомого фахівця з енергетично-безпекових питань Михайла Гончара [21,2]. Моніторинг та оцінка роботи зовнішньополітичних відомств України у протидії побудови «Північного потоку-2», проведення анбандлінгу газотранспортної системи України відповідно до вимог і стандарів Свропейського енергетичного співтовариства та Третього Енергопакету $Є \mathrm{C}$ представлені щорічними оглядами ГО «Рада зовнішньої політики «Українська призма» за підтримки Фонд ім. Ф. Еберта [28].

Попри постійну увагу до безпекових аспектів побудови «Північного потоку-2», актуальність подальших досліджень визначається кількома обставинами. По-перше, високою динамічністю політичної ситуації у ключових країнах (Сполучені Штати, ФРН, Республіка Польща, Україна), двосторонніх відносин і на міжнародній арені. По-друге, домінуванням прикладних за характером досліджень, які методологічну базуються на реалістичній парадигмі теорії міжнародних відносин. Зрештою, по-третє, системного опрацювання потребує аспект економізації зовнішньої політики України в умовах використання Кремлем «енергетичної зброї» як складової гібридної агресії.

Мета дослідження - з'ясувати вплив добудови «Північного потоку-2» на зовнішньоекономічну безпеку України та національну безпеку в цілому, окреслити можливі кроки України у відповідь на загрози та виклики, пов'язані з прокладанням газогону. Для досягнення поставленої мети ми плануємо: розглянути поняття зовнішньоекономічної та енергетичної безпеки держави із застосуванням так званого «широкого підходу» Копенгагенської школи теорії міжнародної безпеки; розкрити пов'язані з добудовою газогону «Північний потік-2» загрози національній безпеці України в контексті викликів енергетичній безпеці Свропи; з'ясувати роль енергетичного фактору в гібридній війні Російської Федерації проти України.

Концептуально наша робота має три методологічних опори. Перша з них - це підхід до розуміння міжнародної безпеки, який склався в рамках Копенгагенської школи, у працях її засновників Б. Бузана і О. Вейвера. У сформульованій ними концепції регіонального комплексу безпеки виокремлюються п'ять секторів безпеки, включно з економічним, інтегруючим серед яких $є$ політичний [31]. В умовах гібридної війни Росії проти України особливої актуальності набуває розуміння взаємовпливу всіх секторів безпеки: військового, політичного, економічного, соціального та екологічного. Друга точка опори полягає у розумінні зовнішньоекономічної безпеки як складової національної безпеки держави, що уособлює здатність державних та недержавних інституцій мінімізувати збитки держави від дії негативних зовнішніх економічних та неекономічних чинників, захищати власні економічні інтереси шляхом запобігання, виявлення та ефективної протидії викликам і загрозам економіці держави, суб'єктам господарювання всіх форм власності, добробуту громадян, а також можливість ефективно, використовуючи участь у світовому поділі праці, сприяти реалізації експортного потенціалу 
та раціоналізації імпорту відповідно до національних інтересів. Нарешті третя методологічна опора це поєднання теоретичних напрацювань у рамках підходів «the four As» та «a vulnerability-based approach to energy security». Таким чином, з одного боку, ми будемо виходити з дещо модифікованої інтерпретації чотирьох базових характеристик енергетичної безпеки:

- ринковість, яка створюється наявністю необхідних об'ємів енергоресурсів для споживачів шляхом забезпечення ринкових умов купівлі-продажу, достатності інвестицій, ефективності правових та регуляторних механізмів;

- надійність, що передбачає безперебійне постачання енергетичних послуг шляхом диверсифікації ланцюгів поставок, палива та технологій, підвищення стійкості інфраструктури;

- доступність, як не лише забезпечення низьких цін для кінцевих споживачів та порівняння цін із доходами кінцевих споживачів, а й стабільність цін, необхідна для планування енергетичних проектів та їх економічна обгрунтованість;

- екологічність, у розумінні ефективного використання енергоресурсів за умов мінімізації негативного впливу на довкілля.

3 іншого боку, ми вважаємо аналітично продуктивним враховувати необхідність відповіді на запитання, сформульовані Алехом Черпом та Джессікою Джюелл, особливо щодо ціннісного виміру енергетичної безпеки. Зауважимо, що методологічне бачення вказаних дослідників грунтується на здобутках Копенгагенської школи теорії безпеки.

На нашу думку, поєднання теоретичних напрацювань двох підходів дасть змогу, по-перше, краще обгрунтувати політичний вимір проблем енергетичної безпеки (нагадаємо, що для Беррі Бузана політичний сектор є інтегруючим), але при цьому, по-друге, не втратити системність розуміння та специфічність економічної безпеки.

Виклад основного матеріалу

Боротьба за природні ресурси триває протягом всього існування людства, змінювався лише перелік цих ресурсів, ієрархія їхзначущості для життєдіяльності. У давнину це золото і срібло. Із розвитком капіталізму - вугілля і залізо, які на прикладі вугільного Саару та залізорудного Ельзасу, спочатку стали економічною причиною війни між Францією і Німеччиною, а далі й однією із суперечностей, що призвели до початку Першої світової війни. Подальша індустріалізація провідних країн світу у XX столітті спричинила попит на нафту та газ. Зрозуміло, що в силу географічного розташування та технологічних досягнень людства доступ до видобутку цих копалин належить лише окремим державам або суб'єктам різної природи власності,серед яких і Росія. Позаяк Російська імперія завжди технологічно поступалася країнам Західної Європи та США, закономірно, що природні багатства становили стабільне й основне джерело доходу від експорту: раніше золото, хутро, ліс, а сьогодні нафта та газ. Але усвідомлення досвіду наслідків періодичних штучних (перша нафтова криза 1973 року) та природніх енергетичних криз дали змогу російській владі використовувати енергоресурси не лише як економічний, але i політичний чинник впливу на держави-покупці, здебільшого європейські. Для координації цього процесу було створено контрольовану державою (50,23\% акцій) газовидобувну і газорозподільну компанію «Газпром». Купівля «Газпромом» «Белтрансгазу», який був посередником упостачанні газу у Свропу магістраллю Ямал-Свропа, введення в експлуатацію «Північного потоку-1» і «Південного потоку» зйого продовженням як «Турецького потоку», ефективна економічна та політична протидія надходженню туркменського газу на європейський ринок створили близьке до монопольного становище російського експорту трубопровідного газу в Свропу. І лише частина використовуваного газогону Уренгой-Помари-Ужгород ідалі у Східну та Західну Європу, яка пролягає на території України, належить українській державі.

Економіка України має свої особливості та проблеми. Щорічний реальний ВВП України у порівнянні з номінальним зберігає негативну тенденцію від'ємного показника, а це свідчить про зростання цін за рахунок інфляції, а не реального збільшення виробництва [17]. Високий ступінь відкритості української економіки (середній показник частки експорту в структурі ВВП сягає 50\%) робить ії вразливою до зовнішнього впливу [11]. Від'ємне сальдо експортно-імпортних операцій зберігається, хоча і зменшилось у 2020 році до $1,1 \%$ ВВП [17]. Український експорт переважно представлений сировиною та товарами з малою доданою вартістю. За ступенем енергоємності українська економіка станом на 2017 рік залишалася на другому місці у світі після Росії, що справляє негативний вплив на конкурентоспроможність українських товарів на світових ринках [13]. Використання водню у зношеній ГТС України за відсутності економічного стимулювання виглядає далекою перспективою. За таких обставин транзит газу через Україну є постійною та вагомою 
статтею доходів бюджету держави (близько 1\% ВВП). Лише за останнім п'ятирічним контрактом Україна отримає від «Газпрому» 7 млрд 200 тис. дол. США [18]. Окрім того, прокачка газу територією України позитивно впливає на стабільність постачання блакитного палива українській промисловості та домогосподарствам. I нарешті, транзит російського газу українським газогоном - це не лише кроки для економічного зростання та забезпечення енергетичної безпеки України, з їі енергоємною економікою, але й участь у підтримці безпекового паливно-енергетичного ланцюга всієї Європи. Та головне, в умовах російсько-української війни транзит газу до Свропи через Україну- це стримуючий фактор для Росії у подальшій військово-політичній ескалації конфлікту. Тому зберігається високий ступінь залежності зовнішньоекономічної і загалом національної безпеки України від збереження потужностей транзиту українською ГТС.

Прокладання ще одного газопроводу «Північний потік-2», розпочата Росією у 2015 році, після анексії Криму та у розпал російсько-української війни на Донбасі, умовно поділила європейські держави на два табори: до першого (прихильники) належать країни, в яких, економічні вигоди від нового газогону домінують над розумінням його політичної небезпеки на чолі з Німеччиною, яка, відмовившись від використання атомної енергетики, прагне стати найбільшим європейським газовим хабом, до другого (противники),- серед яких, насамперед, Україна, Польща та країни Балтії, що реально відчули на собі «російський та радянський чобіт». Добудова, на їхню думку, загрожує економічній, а надалі і національній безпеці. Як результат консолідованої позиції останніх та бачення цієї проблеми Сполученими Штатами стало гальмування будівельних робіт узв'язку із запровадженням Вашингтоном санкцій проти російських і європейських, передусім німецьких, операторів будівництва газогону.

Протидія з боку України «Північному потоку-2» зростала пропорційно швидкості розвитку процесів демократизації і прагнення до євроатлантичної інтеграції після Революції гідності а також позбавлення історичних та новітніх міфів про «русский мир». Так, у 2018 році прем'єр-міністр України В. Гройсман наголошував, що «Північний потік-2»- це форма замаскованої війни проти Європи», а «збереження Україною статусу пріоритетного транзитера газу має велике безпековополітичне значення для всієї Свропи» [10]. Своєю чергою, Президент України П. Порошенко відзначав: «Проект російського газового монополіста «Газпрому» «Північний потік-2»...«не має ніякого економічного сенсу», а «є натомість намаганням Росії послабити Україну, позбавивши ії транзитних зборів» [19]. Окрім політичних аргументів, українські можновладці наводили економічні. Станом на 2018 рік газотранспортна система України, із потужність транспортувати 146 млрд куб. російського газу до Західної Європи, прокачувала лише дещо більше ніж 90 млрд. Економічного сенсу будувати додатковий газогін вартістю у 20 млрд дол. не було [19]. Понад те, Свропі було запропоновано спільне управління українською газотранспортною системою 3 використанням сховищ здатних зберігати запаси до 1000 днів [10].

Для сприяння подальшій євроінтеграції та зміцнення довіри європейських партнерів до нашої держави, відповідно до Третього енергопакету $Є \mathrm{C}$, метою створення якого $є$ демонополізація енергетичних ринків країн $\mathrm{CC}$, у 2020 році було завершено анбандлінг газотранспортної системи України: відокремлення управління газотранспортної системи України від Нафтогазу. Це дало змогу укласти п’ятирічний контракт із «Газпромом» уже за європейськими правовими нормами та за посередництва країн-членів $Є C$, отримати додаткові важелі впливу у протидії побудові «Північногопотоку-2». Однак на не достатню ефективність боротьби проти побудови газогону Росією, який станом на кінець червня 2021 року збудований на 98\%, вплинули як внутрішні, так й зовнішні обставини. За всієї дискусійності цієї тези, не варто ігнорувати певну «втому» західних партнерів від влади України, яка певні гасла і обіцянки не втілює належним чином у конкретні справи. Наприклад, ступінь реформування Україною ринку електричної енергії відповідно до вимог Третього енергопакету ЄС протягом 10 років становить лише 48\% [26]. Свропейські та світові інститути (СС, СБРР, Світовий банк, IFC) невдоволені порушенням стандартів корпоративного управління під час зміні керівництва Нафтогазу України в квітні 2021 року, що негативно позначилося на довірі до української влади та інвестиційному кліматі в державі. Окрім того, позитивній динаміці будівництва «Північного потоку-2» сприяють тісні та навіть «родинні» зв'язкі російських та українських олігархічних кіл. Заради об'єктивності варто зазначити, що Україна дещо із запізненням включилась у процес протидії будівництву російського газогону, тому що першорядним було питання збереження суверенітету в умовах анексії Росією Криму та окупації нею частини Донбасу. Наявні також помилки економічної дипломатії України: недооцінка важливості економізації зовнішньої політики, зокрема 
Що стосується зовнішніх факторів, то сьогодні кульмінаційним моментом у добудові «Північного потоку-2» стала угода від 22 липня 2021 року між очільниками США та Німеччини. Саме кульмінацією, адже вона $є$ продовженням тривалої тенденції до схильності частини західних лідерів шукати способи «домовлятися» з Кремлем. На нашу думку, остання американо-німецька угода $€$ не просто фактором двосторонніх відносин, вона радше $\epsilon$ результатом складного комплексу перемовин Президента США Д. Байдена з лідерами країн G7, членами НАTO та його зустрічі з Президентом Росії В. Путіним у червні цього року. У контексті нашого дослідження розглянемо їі результати та можливі наслідки для України: виклики, загрози, перспективи.

Обговорення питань, які безпосередньо стосувалися України, відбувалось без України, що $є$ певною оцінкою рівня суб'єктності нашої держави. Враховуючи, що документ, підписаний Вашингтоном і Берліном не має статусу міжнародної угоди (ії офіційна назва «Спільна заява США та Німеччини про підтримку України, європейської енергетичної безпеки та наших кліматичних цілей» [23]), формально не стосується «Північного потоку-2», та зважаючи на інформацію, поширену виданням «Politico» про те, що адміністрація США нібито закликала Україну утриматись від критики домовленостей [6], виникає сумнів у прозорості та дієвості американо-німецьких домовленостей. За спільною американо-німецькою заявою Україна отримує «розмиті» гарантії Німеччини, у разі використання Росією енергетики як зброї, закликати ЄС вжити заходів включно з санкціями. Але можливі санкції вплинуть на прибутковість і безпеку німецької економіки, а це означає «рубати гілку на якій сидиш», а також на перспективу опору з боку частини німецького бізнесу Не переконливими виглядають зобов" язання Німеччини «використовувати всі наявні важелі для сприяння продовженню на 10 років угоди України про транзит газу з Росією» [14] та підтримка цих зусиль США, оскільки виникають сумні аналогії з виконанням гарантій Будапештського меморандуму. Задекларовані в документі потенційні економічні «вигоди» України: 200 млн євро додаткової допомоги Україні, 70 млн. євро на реалізацію україно-німецьких проектів у галузі енергетики та фонд у 1 млрд дол. для фінансування інвестицій для переходу України на відновлювані джерела енергії і підвищення енергетичної безпеки, з першим внесок Німеччини у фонд в розмірі 175 млн дол. США [23] не покривають навіть річні втрати від транзиту російського газу за останнім контрактом України з «Газпромом» (1,5-2 млрд дол) у разі його не пролонгації. Проєкт Берліну щодо спрямування європейських інвестицій в український енергетичний сектор у обсязі 1,77 млрд дол США [25], враховуючи неоднозначність позицій і думок членів СС, виглядає далекою і примарною перспективою. Найбільш реалістичними $є$ пункти домовленостей щодо реверсного постачання газу в Україну, модернізації іiі ГТС та використання обох «Північних потоків» на 50\%. Хоча і тут на пам'яті «газові війни» 2009 року, коли Європа переймалась лише своєю енергетичною безпекою, а також порушення Брюсселем у жовтні 2016 року статті 274 угоди про Асоціацію України з СС шляхом дозволу додаткової прокачки російського газу через «Північний потік-1» в обхід України.

Оскільки проаналізована угода між США та Німеччиною, на нашу думку, не гарантує зовнішньоекономічної безпеки України, розглянемо можливі загрози після добудови «Північного потоку-2». Почнемо з економічних. Як виявилось, поки що відсутні впливові політичні актори, які можуть або бажають гарантувати транзит газу територією України. Враховуючи, що добудова «Південного потоку» вплинула на скорочення об'ємів прокачки газу через Україну на $15 \%$, після запуску «Північного потоку-2» Україна може не доотримати 1,5-2 млрд дол США «транзитних коштів» щороку. А запевнення західних і російських урядовців про обов'язкове транспортування газу територією України в межах 25 млрд куб. м на рік не розв'язує питання, тому що, по-перше, існують обгрунтовані сумніви щодо виконання, по-друге, такий обсяг газу не рентабельний для технологічних потужностейукраїнської ГТС. У червні - липні 2021 року Росія штучно створила дефіцит газу в Свропі: скоротила закачування газу в підземні сховища Європи газопроводами Ямал-Свропа та через Україну у понад 1,5 раза [12], що спричинило зростання цін на блакитне паливо до рекордних показників за останні вісім років: 525 дол США за тис м3. Наведені факти вкотре засвідчують використання газового питання Росією як засобу економічного шантажу та можливості отримати надприбутки монополістом «Газпромом», які експерти лише у липні 2021 року оцінюють у 1,5 млрд дол [7].

Екологічні ризики. Не використання ГТС України призведе до ії занепаду, не можливості відновлення у подальшому та екологічних проблем. Однак найбільша загроза пов'язана із введенням в експлуатацію «Північного потоку-2», оскільки у місці видобутку газу на Ямалі та за маршрутом на компресорних станціях різко зростуть викиди метану та діоксиду вуглецю, які активно впливають на глобальне потепління, і з яким, до речі, прагнуть боротися і Європа, і США. 
Однак найбільш серйозними є політико-безпекові загрози. Без використання ГТС України Європа на 80\% залежатиме від газогонів «Газпрому» [1], тому, як відомо, монополія економічна породжує монополію у політиці. На службу у «Газпромі» його філіях, дочірніх та залежних від нього компаніях працевлаштована значна кількість впливових європейських політиків на кшалт $Г$. Шредера, а коштами фактично державного російського газового монополіста «Газпром» спонсорується діяльність лівих та правих радикальних політичних сил у багатьох країнах Європи. Втрата транзиту газу через Україну може призвести до зростання ризику не тільки політичного тиску на Україну але й повномасштабної військової агресії Росії, адже це не зачіпатиме європейських споживачів. На думку М. Гончара: «Росія використовуватиме цивільну інфраструктуру новозбудованого газопроводу не лише за прямим призначенням, а й для нарощування військового домінування» [8]. I ще один вкрай важливий аспект стосується наслідків для суб'єктності України на міжнародній арені. Мотив Дж. Байдена в перегляді ставлення до санкцій стосовно «Північного потоку-2» $є$ цілком зрозумілим: відновлення трансатлантичної єдності, передусім нормалізація відносин з Німеччиною, яка серйозна постраждала від президенства Дональда Трампа. Але маємо підстави підозрювати, попри чисельні заспокійливі заяви американських посадовців різного рангу, що реалізація цього завдання може відбуватися за рахунок інтересів України.

3 огляду на окреслені загрози та виклики від добудови «Північного потоку-2» та складний технологічний, юридичний i політичний механізм прийняття його в експлуатацію, окреслимо можливі подальші кроки України, необхідні для нейтралізації негативних наслідків цього проєкту.

Відзначимо оперативність дій української влади щодо мобілізації підтримки союзників 3 протидії добудови газогону: спільна заява очільників МЗС України та Польщі від 21 липня 2021 року про консолідовану співпрацю в цьому напрямі, ініціювання Києвом консультацій щодо «Північного потоку-2» відповідно до статті 274 Угоди про асоціацію України з СС [4]. Адже у разі завершення запуску обхідних газогонів по Балтиці та Чорному морі в обхід України і Польщі зростає небезпека монополізації європейського газового ринку російським «Газпромом». Далі, уряд України 4 серпня 2021 року затвердив енергетичну стратегію безпеки України, яка передбачає три імовірних прогнозних сценарії змін в енергетичній сфері та їх впливу в середньостроковій перспективі, за другим з яких, «недружнього впливу», додатково до реалізації сценарію першого, «без змін», передбачається реагування на зростання зовнішнього впливу РФ, спрямованого на отримання контролю над енергетичною політикою України [29]. Для подальшого розширення кола публічного спілкування щодо небезпеки добудови «Північного потоку-2» проведено консультації з японським МЗС. Певні надії маємо у зв'язку з широким представництвом зареєстрованих учасників високого рангу на саміті «Кримської платформи», та візитом Президента України В. Зеленського в США для зустрічі з Д. Байденом 30 серпня 2021 року.

Перспективними також виглядають наступні дії української влади. У контексті протидії України, Польщі, країн Балтії російським газовим потокам необхідно спільно зосередити роботу з законодавчими органами США у відновленні санкцій та сприяти проведенню розслідувань американськими компетентними органами діяльності симбіозу політичних та економічних суб'єктів, що шкодять спільним європейським та американським інтересам. Підгрунтя для такої роботи існує. 3 серпня 2021 року голова комітету з міжнародних відносин Сенату США Роберт Менендес та 10 його колег з країн СС підписали спільну заяву, в якій висловилися проти домовленості США та Німеччини щодо газопроводу «Північний потік-2» [9]. 3 огляду на вагомість сертифікації «Північного потоку-2» для його функціонування та прецедент 3 перемогою у європейському суді польської газової компанії PGNiG, яка полягає у скасуванні права «Газпрому» використовувати газогін OPAL на 90\%, а дозволяє лише на 50\%, Україні необхідно підтримувати подальші кроки Польщі, а саме участь згаданої державної польської компанії у процедурі сертифікації оператора газопроводу «Північний потік-2» [18] з метою демонополізації європейського газового ринку та запропонувати свої ефективні заходи у цьому напрямі. Економічним і політичним кроком може бути запрвадження Україною власних санкцій проти німецької компанії-оператора Nord Stream 2 AG та ініціювання розслідування іiі діяльності щодо дотримання законодавства ЄС. Необхідно акцентувати увагу світової спільноти на можливості використання інфраструктури «Північного потоку-2» для ведення підривної діяльності на території країн-членів СС і НАТО.

Варто «підвищити градус» у дискусіях щодо екологічної загрози. Країни Європи та США могли б сприяти забороні подальшого використання енергетичних родовищ Арктики, що розробляються Росією з ігноруванням екологічних вимог, а потужності обох «Північних потоків» обмежити до 50\% 3 обкладанням транспортованого газу екологічним податком з викидів вуглецю [2]. Україні потрібно 
особливу увагу зосередити на розробках власних газових родовищ, особливо на Харківщині, де видобувається до 45\% об'ємів національного газовидобутку. Важливо зосередитись на енергозберігаючих технологіях та розвитку «зеленої» енергетики. Амбітні плани європейських країн і України, зокрема зі скорочення викидів вуглецю та активного використання альтернативних джерел енергії- це шлях до «осушування» російської газової труби та знищення економічного фундаменту агресії Росії. Проте зовнішні успіхи України можливі лише за умови виконання «домашньої» роботи всередині країни. Боротьба з корупцією, детінізація та деолігархізація української економіки та політики не тільки сприятимуть успішності реформ, вони зроблять Україну інвестиційно привабливою, закріплять імідж надійного партнера, перешкоджатимуть сповзанню до статусу об'єкта світової політики.

Однак, з огляду на розуміння того, що економічна та енергетична безпека є складовими національної безпеки, своєрідна стратегічна рамка (strategic framework) відповіді України на енергетичний шантаж з боку Росії має формуватися в руслі успішного втілення внутрішніх реформ, а також реалізації завдань євроатлантичної та європейської інтеграції. Саме ефективність реформування українського суспільства на засадах демократії та цивілізованого ринку, динамічне втілення євроатлантичного та європейського курсів створюють фундамент національної безпеки. Не менш важливим є системне прогнозування загроз та вироблення сценаріїв реакції на них. Наведемо кілька прикладів. Статус основного союзника США поза НАТО часто розглядається експертами як проміжний «замінник» повноправному членству в Альянсі. Але фахівці Ради зовнішньої політики "Українська призма" аргументовано вказують на неоднозначність такого варіанта наших дій, що варто враховувати для уникнення непотрібної ейфорії та оптимізму [15]. Не менш небезпечним $\epsilon$ односторонній погляд на перспективи нафтогазової моделі російської економіки [5]. В даному випадку проблема має як мінімум два «але». По-перше, очевидна криза нафтогазової моделі може стати аргументом у протидії Москві лише в разі ефективного використання Брюсселем і Києвом цих недоліків в обмеженні енергетичних амбіцій Кремля. По-друге, колапс нафтогазової моделі може перетворитися на фактор ще більш непередбачуваної та агресивної поведінки «колективного Путіна».

\section{Висновки}

Таким чином, маємо підстави зробити наступні висновки на підсумок нашого аналізу. Добудова «Північного потоку-2» безумовно становить серйозну загрозу економічній та енергетичній безпеці не тільки України, але й Європи. Загроза для нашої країни в разі реалізації російського проєкту $є$ комплексною, стосується не лише економіки та енергетики, але всієї системи національної безпеки, включно з дестабілізацією внутрішньої політичної ситуації. Як обгрунтовано вважають представники Копенгагенської школи, ключовим елементом цієї загрози є політичний. Ніхто з неупереджених політиків й експертів не має сумнівів, що проєкт $є$ не бізнесовим, а геополітичним за своєю природою. Українській владі у формуванні стратегії протидії його негативним наслідкам варто спиратися на ціннісну тезу прибічників «поглибленого підходу» в розумінні енергетичної безпеки. Без того, щоб ключові європейські споживачі російського газу не повернулися до ціннісних засад у своєму ставленні до політики Кремля, перспективи створення об'єднаного фронту протистояння російській гібридній війні є маловірогідними. Без такого об'єднаного фронту Україні буде вкрай складно чинити опір агресивній поведінці Російської Федерації. Останнє означає, що стратегія Києва повинна гармонійно поєднувати зусилля з успішності внутрішніх реформ, мобілізації внутрішнього потенціалу укріплення економічної, енергетичної безпеки та просування цінностей як основи політики Заходу щодо Росії, координації української позиції з тими країнами Заходу, які чітко усвідомлюють ризики і загрози загравання з Москвою на основі принципу «business as usual».

\section{Бібліографічний список:}

1. Без газотранспортної системи України Свропа на 80\% залежатиме від газогонів «Газпрому URL:https://mind.ua/news/20229355-bez-gazotransportnoyi-sistemi-ukrayini-evropa-na-80-zalezhatimevid-gazogoniv-gazpromu-sergij-mako.

2. Вісім кроків для перемоги над Nord Stream-2. чому боротьбу ще не завершено.

URL: https://www.eurointegration.com.ua/experts/2021/07/23/7125777/.

3. Вітренко: битва проти «Північного потоку-2» програна, але війна триває.

URL: https://www.radiosvoboda.org/a/news-vitrenko-pivnichnyi-potik-viina-tryvaie/31386975.html

4. В ЄС оцінили кмітливу реакцію Києва на угоду щодо «Північного потоку-2»

URL: https://www.eurointegration.com.ua/news/2021/07/27/7125920/.

5. Владимиров В. Грядущий коллапс нефтегазовой модели: конец паразитированию на природной ренте? URL.: https://www.golosameriki.com/a/upcoming-collapse-of-the-oil-and-gas-model/5993018.html. 
6. В України є свій голос - радник Держдепартаменту США про статтю Politico. 21 липня 2021.

URL.: https://www.radiosvoboda.org/a/news-sholle-pivnichnyi-potik2-politico/31369965.html.

7. Газпром маніпуляціями на євроринку міг у липні збільшити дохід на 1,5 мільярда євро.

URL: https://www.epravda.com.ua/news/2021/07/30/676449/.

8. Геополітична загроза для всього світу

URL: https://www.epravda.com.ua/rus/projects/gazpravda/2021/06/14/674860/.

9. Глави міжнародних комітетів 9 парламентів виступили проти URL: «Північного потоку-2»

URL: https://www.eurointegration.com.ua/news/2021/08/3/7126146/.

10. Гройсман про «Північний потік-2»: це прихована війна проти Свропи

URL: https://www.radiosvoboda.org/a/news-hroisman-pivnichnyi-potik-2/29633511.html.

11. Експорт та імпорт України. Мінфін. URL: https://index.minfin.com.ua/ua/economy/gdp/eximp/ (дата звернення 13.07.2021).

12. Енергетична зброя Кремля в дії. Газпром скоротив і поставки газу до Свропи, і закачування у сховища. URL: https://biz.nv.ua/ukr/markets/rosiya-i-deficit-gazu-v-yevropi-gazprom-zmenshiv-prokachuvannya-izapovnennya-shovishch-50175015.html

13. Енергоємність економіки України, або чому до Європи ще далеко (дата звернення 04.07.2021).

14. За лаштунками газової поразки. URL: https://www.eurointegration.com.ua/articles/2021/07/22/7125718/.

15. Краєв О. Статус основного союзника США поза НАТО - мрія чи близька перспектива. Київ: Рада зовнішньої політики «Українська призма», 2021. 33 с.

16. Economic Security: Neglected Dimension of National Security. Ed. by Sh. R. Ronis. Washington: National Defense University Press, 2011. 128 p.

17. Минфин. URL: https://index.minfin.com.ua/economy/gdp/ (дата звернення 04.07.2021).

18. Польська компанія планує взяти участь у сертифікації «Північного потоку-2»

URL: https://www.ukrinform.ua/rubric-world/3290988-polska-kompania-pgnig-planue-vzati-ucast-u-sertifikaciipivnicnogo-potoku2.html.

19. Порошенко Німеччині: не потрапте в Путінову газову пастку

URL: https://www.radiosvoboda.org/a/news-poroshenko-nimechchyna-pivnichnyi-potik-2-rosija/29504155.html.

20. Представник США в Україні не вважає 2 «вирішеним» питання щодо «Північного потоку-2» URL: https://news.ternopil.ua/post1441848.

21. Рецепти поразки: 7 тез про те, чому США та СС програли лобістам "Північного потоку-2". URL: https://www.eurointegration.com.ua/experts/2021/07/22/7125730/.

22. Спільна заява міністра закордонних справ України Дмитра Кулеби та міністра закордонних справ Польщі Збігнєва Рау щодо Північного потоку-2 URL: https://mfa.gov.ua/news/spilna-zayava-ministrazakordonnih-sprav-ukrayini-dmitra-kulebi-ta-ministra-zakordonnih-sprav-polshchi-zbignyeva-rau-shchodopivnichnogo-potoku-2

23. Спільна заява Сполучених Штатів Америки і Німеччини щодо підтримки України, європейської енергетичної безпеки та спільних кліматичних цілей URL:

https://ua.usembassy.gov/uk/joint-statement-of-the-united-states-and-germany-on-support-for-ukraine-europeanenergy-security-and-our-climate-goals/.

24. Стратегія національної безпеки України «Безпека людини - безпека країни». Затверджена Указом Президента України від 14 вересня 2020 року № 392/2020. URL.: https://www.president.gov.ua/documents/ 3922020-35037.

25. Угода між США і ФРН щодо "Північного потоку-2": обіцянки транзиту і грошей для Києва URL: https://www.dw.com/uk/uhoda-mizh-ssha-i-frn-shchodo-pivnichnoho-potoku-2-obitsianky-tranzytu-i-hrosheidlia-kyieva/a-58584902.

26. Україна за 10 років імплементувала Третій енергопакет по ринку е/е лише на $48 \%$ URL:https://expro.com.ua/novini/ukrana-za-10-rokv-mplementuvala-trety-energopaket-po-rinku-ee-lishe-na-48.

27. Україна, Польща невдоволені домовленістюНімеччини і США щодо Північного потоку- 2 .

URL: https://ukrainian.voanews.com/a/ukraine-poland-hit-back-at-us-germany-nord-stream-deal/5974923.html.

28. Українська призма: зовнішня політика 2019. К.: ГО «Рада зовнішньої політики «Українська призма», Фонд ім. Фрідріха Еберта, 2020. 390 с.

29. Уряд затвердив Стратегію енергетичної безпеки України. URL: https:/expro.com.ua/novini/uryadzatverdiv-strategyu-energetichno-bezpeki-ukrani.

30. Уряд схвалив проект Стратегії економічної безпеки України на період до 2025 року.

URL.: https://www.kmu.gov.ua/news/uryad-shvaliv-proekt-strategiyi-ekonomichnoyi-bezpeki-ukrayini-na-perioddo-2025-roku.

31. Buzan B., Wæver O., Wilde de J. Security. A Framework for Analysis. London: Lynne Rienner Publishers, 1998. $240 \mathrm{p}$.

32. Cherp A., Jewell J. The concept of energy security: Beyond the four As. Energy Policy. 2014. Vol. 75. P. 415-421

33. Economic Security: Neglected Dimension of National Security. Ed. by Sh. R. Ronis. Washington: National Defense University Press, 2011. 128 p. 
34. Jones O., Dodds, P.E. Definitions of energy security. The role of hydrogen and fuel cells in delivering energy security for the UK., London: H2FC Supergen, 2017. P. 21-34

35. FAST THINKING: Nord Stream 2 gets the green light. URL: https://www.atlanticcouncil.org/contentseries/fastthinking/fast-thinking-nord-stream-2-gets-the-green-light/.

36. Morgenthau H.J. The Economics of Foreign Policy. Challenge. 1959. February. P. 8-13.

\section{References:}

1. Bez hazotransportnoi systemy Ukrainy Yevropa na $80 \%$ zalezhatyme vid hazohoniv «Hazpromu URL:https://mind.ua/news/20229355-bez-gazotransportnoyi-sistemi-ukrayini-evropa-na-80-zalezhatimevid-gazogoniv-gazpromu-sergij-mako.

2. Visim krokiv dlia peremohy nad Nord Stream-2. chomu borotbu shche ne zaversheno.

URL: https://www.eurointegration.com.ua/experts/2021/07/23/7125777/.

3. Vitrenko: bytva proty «Pivnichnoho potoku-2» prohrana, ale viina tryvaie.

URL: https://www.radiosvoboda.org/a/news-vitrenko-pivnichnyi-potik-viina-tryvaie/31386975.html

4. V YeS otsinyly kmitlyvu reaktsiiu Kyieva na uhodu shchodo «Pivnichnoho potoku-2»

URL: https://www.eurointegration.com.ua/news/2021/07/27/7125920/.

5. Vladymyrov V. Hriadushchyi kollaps neftehazovoi modely: konets parazytyrovanyiu na pryrodnoi rente?

URL.: https://www.golosameriki.com/a/upcoming-collapse-of-the-oil-and-gas-model/5993018.html.

6. V Ukrainy ye svii holos - radnyk Derzhdepartamentu SShA pro stattiu Politico. 21 lypnia 2021.

URL.: https://www.radiosvoboda.org/a/news-sholle-pivnichnyi-potik2-politico/31369965.html.

7. Hazprom manipuliatsiiamy na yevrorynku mih u lypni zbilshyty dokhid na 1,5 miliarda yevro.

URL: https://www.epravda.com.ua/news/2021/07/30/676449/.

8. Heopolitychna zahroza dlia vsoho svitu URL: https://www.epravda.com.ua/rus/projects/gazpravda/ 2021/06/14/674860/.

9. Hlavy mizhnarodnykh komitetiv 9 parlamentiv vystupyly proty URL: «Pivnichnoho potoku-2»

URL: https://www.eurointegration.com.ua/news/2021/08/3/7126146/.

10. Hroisman pro «Pivnichnyi potik-2»: tse prykhovana viina proty Yevropy

URL: https://www.radiosvoboda.org/a/news-hroisman-pivnichnyi-potik-2/29633511.html.

11. Eksport ta import Ukrainy. Minfin. URL: https://index.minfin.com.ua/ua/economy/gdp/eximp/ (data zvernennia 13.07.2021).

12. Enerhetychna zbroia Kremlia v dii. Hazprom skorotyv i postavky hazu do Yevropy, i zakachuvannia u skhovyshcha. URL: https://biz.nv.ua/ukr/markets/rosiya-i-deficit-gazu-v-yevropi-gazprom-zmenshivprokachuvannya-i-zapovnennya-shovishch-50175015.html

13. Enerhoiemnist ekonomiky Ukrainy, abo chomu do Yevropy shche daleko (data zvernennia 04.07.2021).

14. Za lashtunkamy hazovoi porazky. URL: https://www.eurointegration.com.ua/articles/2021/07/22/7125718/.

15. Kraiev O. Status osnovnoho soiuznyka SShA poza NATO - mriia chy blyzka perspektyva. Kyiv: Rada zovnishnoi polityky «Ukrainska pryzma», 2021. $33 \mathrm{~s}$.

16. Economic Security: Neglected Dimension of National Security. Ed. by Sh. R. Ronis. Washington: National Defense University Press, 2011. 128 p.

17. Mynfyn. URL: https://index.minfin.com.ua/economy/gdp/ (data zvernennia 04.07.2021).

18. Polska kompaniia planuie vziaty uchast u sertyfikatsii «Pivnichnoho potoku-2»

URL: https://www.ukrinform.ua/rubric-world/3290988-polska-kompania-pgnig-planue-vzati-ucast-u-sertifikaciipivnicnogo-potoku2.html.

19. Poroshenko Nimechchyni: ne potrapte v Putinovu hazovu pastku

URL: https://www.radiosvoboda.org/a/news-poroshenko-nimechchyna-pivnichnyi-potik-2-rosija/29504155.html.

20. Predstavnyk SShA v Ukraini ne vvazhaie 2 «vyrishenym» pytannia shchodo «Pivnichnoho potoku-2» URL: https://news.ternopil.ua/post1441848.

21. Retsepty porazky: 7 tez pro te, chomu SShA ta YeS prohraly lobistam "Pivnichnoho potoku-2".

URL: https://www.eurointegration.com.ua/experts/2021/07/22/7125730/.

22. Spilna zaiava ministra zakordonnykh sprav Ukrainy Dmytra Kuleby ta ministra zakordonnykh sprav Polshchi Zbihnieva Rau shchodo Pivnichnoho potoku-2 URL: https://mfa.gov.ua/news/spilna-zayava-ministra-zakordonnihsprav-ukrayini-dmitra-kulebi-ta-ministra-zakordonnih-sprav-polshchi-zbignyeva-rau-shchodo-pivnichnogo-potoku-2

23. Spilna zaiava Spoluchenykh Shtativ Ameryky i Nimechchyny shchodo pidtrymky Ukrainy, yevropeiskoi enerhetychnoi bezpeky ta spilnykh klimatychnykh tsilei URL:

https://ua.usembassy.gov/uk/joint-statement-of-the-united-states-and-germany-on-support-for-ukraine-europeanenergy-security-and-our-climate-goals/.

24. Stratehiia natsionalnoi bezpeky Ukrainy «Bezpeka liudyny - bezpeka krainy». Zatverdzhena Ukazom Prezydenta Ukrainy vid 14 veresnia 2020 roku № 392/2020. URL.: https://www.president.gov.ua/documents/ 3922020-35037.

25. Uhoda mizh SShA i FRN shchodo "Pivnichnoho potoku-2": obitsianky tranzytu i hroshei dlia Kyieva URL: https://www.dw.com/uk/uhoda-mizh-ssha-i-frn-shchodo-pivnichnoho-potoku-2-obitsianky-tranzytu-i-hrosheidlia-kyieva/a-58584902. 
26. Ukraina za 10 rokiv implementuvala Tretii enerhopaket po rynku e/e lyshe na $48 \%$

URL:https://expro.com.ua/novini/ukrana-za-10-rokv-mplementuvala-trety-energopaket-po-rinku-ee-lishe-na-48.

27. Ukraina, Polshcha nevdovoleni domovlenistiuNimechchyny i SShA shchodo Pivnichnoho potoku-2.

URL: https://ukrainian.voanews.com/a/ukraine-poland-hit-back-at-us-germany-nord-stream-deal/5974923.html.

28. Ukrainska pryzma: zovnishnia polityka 2019. K.: HO «Rada zovnishnoi polityky «Ukrainska pryzma», Fond im. Fridrikha Eberta, 2020. $390 \mathrm{~s}$.

29. Uriad zatverdyv Stratehiiu enerhetychnoi bezpeky Ukrainy. URL: https://expro.com.ua/novini/uryadzatverdiv-strategyu-energetichno-bezpeki-ukrani.

30. Uriad skhvalyv proekt Stratehii ekonomichnoi bezpeky Ukrainy na period do 2025 roku.

URL.: https://www.kmu.gov.ua/news/uryad-shvaliv-proekt-strategiyi-ekonomichnoyi-bezpeki-ukrayini-na-perioddo-2025-roku.

31. Buzan B., Wæver O., Wilde de J. Security. A Framework for Analysis. London: Lynne Rienner Publishers, 1998. $240 \mathrm{p}$.

32. Cherp A., Jewell J. The concept of energy security: Beyond the four As. Energy Policy. 2014. Vol. 75. P. $415-421$

33. Economic Security: Neglected Dimension of National Security. Ed. by Sh. R. Ronis. Washington: National Defense University Press, 2011. 128 p.

34. Jones O., Dodds, P.E. Definitions of energy security. The role of hydrogen and fuel cells in delivering energy security for the UK., London: H2FC Supergen, 2017. P. 21-34

35. FAST THINKING: Nord Stream 2 gets the green light. URL: https://www.atlanticcouncil.org/content-series/ fastthinking/fast-thinking-nord-stream-2-gets-the-green-light/.

36. Morgenthau H.J. The Economics of Foreign Policy. Challenge. 1959. February.

\section{Kotik Y. V. Completion of the Nord Stream-2 in the Context of Ukraine's Foreign Economic Security}

The article reveals the essential characteristics of the impact of the construction of Nord Stream-2 on the foreign economic security of Ukraine, which confirms the growing relevance of economic security on the agenda of the theory and practice of national security in general. It turns out that the "extended" interpretation of energy security allows us to go beyond the economic and technological vision of the problem and consider it as a socio-political component that has taken on a new dimension as an influential tool in world politics. The issue of energy supplies from Russia to Europe clearly demonstrates the interdependence of energy security in Europe and Ukraine. Russia's hybrid war against Ukraine proves the interplay of all security sectors: military, political, economic, social and environmental, with an integrative political one, in line with the Copenhagen school's approach to understanding international security. It is alleged that it depends on Ukraine's foreign economic and national security in general. From the preservation of transit capacity of the Ukrainian GTS and the completion of Nord Stream-2 Objectives and subjective factors that influenced the construction of the Nord Stream-2 gas pipeline, the role of the United States, the EU, Russia and Ukraine in this process. Since the analyzed agreement between the United States and Germany of July 22, 2021 does not guarantee Ukraine's foreign economic security, possible threats after the completion of Nord Stream-2 were considered: economic, environmental and political security. Given the complex technological, legal and political mechanism of commissioning of the Russian gas pipeline, the possible further steps of Ukraine necessary to neutralize the negative consequences of this project are outlined. Emphasis is placed on the need to create a united front to counter the Russian hybrid war by returning key European consumers of Russian gas to values in their attitude to Kremlin policy.

Keywords: foreign economic security, energy security, economic diplomacy, «Nord Stream-2», national interests. 